\title{
The $\mathbf{C 2}$ domains of granuphilin are high-affinity sensors for plasma membrane lipids
}

\author{
Tatyana A. Lyakhova and Jefferson D. Knight ${ }^{\star}$ \\ Department of Chemistry, University of Colorado Denver, Campus Box 194, P.O. Box 173364, \\ Denver, CO 80217 USA
}

\section{Abstract}

Membrane-targeting proteins are crucial components of many cell signaling pathways, including the secretion of insulin. Granuphilin, also known as synaptotagmin-like protein 4, functions in tethering secretory vesicles to the plasma membrane prior to exocytosis. Granuphilin docks to insulin secretory vesicles through interaction of its $\mathrm{N}$-terminal domain with vesicular Rab proteins; however, the mechanisms of granuphilin plasma membrane targeting and release are less clear. Granuphilin contains two $\mathrm{C} 2$ domains, $\mathrm{C} 2 \mathrm{~A}$ and $\mathrm{C} 2 \mathrm{~B}$, that interact with the plasma membrane lipid phosphatidylinositol-(4,5)-bisphosphate $\left[\mathrm{PI}(4,5) \mathrm{P}_{2}\right]$. The goal of this study was to determine membrane-binding mechanisms, affinities, and kinetics of both granuphilin $\mathrm{C} 2$ domains using fluorescence spectroscopic techniques. Results indicate that both $\mathrm{C} 2 \mathrm{~A}$ and $\mathrm{C} 2 \mathrm{~B}$ bind anionic lipids in a $\mathrm{Ca}^{2+}$-independent manner. The $\mathrm{C} 2 \mathrm{~A}$ domain binds liposomes containing a physiological mixture of lipids including $2 \% \mathrm{PI}(4,5) \mathrm{P}_{2}$ or $\mathrm{PI}(3,4,5) \mathrm{P}_{3}$ with high affinity (apparent $K_{\mathrm{d} \text {,PIPx }}$ of $2-5$ $\mathrm{nM}$ ), and binds nonspecifically with moderate affinity to anionic liposomes lacking phosphatidylinositol phosphate $\left(\mathrm{PIP}_{\mathrm{x}}\right)$ lipids. The $\mathrm{C} 2 \mathrm{~B}$ domain binds with sub-micromolar affinity to liposomes containing $\mathrm{PI}(4,5) \mathrm{P}_{2}$ but does not have a measurable affinity for background anionic lipids. Both domains can be competed away from their target lipids by the soluble PIP $_{\mathrm{x}}$ analogue inositol-(1,2,3,4,5,6)-hexakisphosphate ( $\left.\mathrm{IP}_{6}\right)$, which is a positive regulator of insulin secretion. Potential roles of these interactions in the docking and release of granuphilin from the plasma membrane are discussed.

\section{Keywords}

Slp4; protein-lipid interaction; secretory granule docking; inositol polyphosphate signaling; insulin secretion; phosphatidylinositol-(4,5)-bisphosphate

\footnotetext{
(C) 2013 Elsevier Ireland Ltd. All rights reserved.

*Author to whom correspondence should be addressed jefferson.knight@ ucdenver.edu Voice: 303-556-6639 Fax: 303-556-4776. Publisher's Disclaimer: This is a PDF file of an unedited manuscript that has been accepted for publication. As a service to our customers we are providing this early version of the manuscript. The manuscript will undergo copyediting, typesetting, and review of the resulting proof before it is published in its final citable form. Please note that during the production process errors may be discovered which could affect the content, and all legal disclaimers that apply to the journal pertain.
} 


\section{Introduction}

Protein domains that interact reversibly with lipid membranes serve as signaling modules in a variety of cellular processes (Cho and Stahelin, 2005; Lemmon, 2008). C2 domains represent one of the most abundant families of membrane-targeting domains and typically dock to anionic lipid membranes in response to $\mathrm{Ca}^{2+}$, although some members sense phosphatidylinositol phosphate $\left(\mathrm{PIP}_{\mathrm{x}}\right)$ lipids in addition to, or instead of, cytosolic $\mathrm{Ca}^{2+}$ (Corbalan-Garcia et al., 2003; Murray and Honig, 2002; Nalefski and Falke, 1996). C2 domains are highly represented among proteins in regulated secretory pathways, including synaptotagmin and related proteins that serve as $\mathrm{Ca}^{2+}$ and/or lipid sensors in secretory vesicle docking and exocytosis (Fukuda and Mikoshiba, 2001; Gustavsson and Han, 2009; Martens, 2010; Sudhof, 2002).

The synaptotagmin-like protein granuphilin (also known as Slp-4) contains an N-terminal domain that attaches to Rab27a/Rab3 on secretory vesicles, a linker region of unknown structure that mediates binding to syntaxin and/or Munc18 on the plasma membrane, and two C-terminal C2 domains, termed C2A and C2B (Coppola et al., 2002; Torii et al., 2004; Tsuboi and Fukuda, 2006; Wang et al., 1999; Yi et al., 2002). Both C2 domains have been shown qualitatively to bind lipid vesicles containing phosphatidylinositol-(4,5)-bisphosphate [PI(4,5) $\mathrm{P}_{2}$ or $\left.\mathrm{PIP}_{2}\right]$ independently of $\mathrm{Ca}^{2+}$ (Yu et al., 2007), but little else is known about their membrane binding properties. The role of $\mathrm{C} 2$ domain-plasma membrane interaction for granuphilin function is somewhat controversial; some models indicate direct C2 domain interaction with plasma membrane lipids, while others suggest that granuphilin plasma membrane docking is mediated solely by its linker region binding Munc18/syntaxin (Izumi, 2011; Tsuboi, 2009). Recent evidence indicates that deletion of both $\mathrm{C} 2$ domains from granuphilin leads to a cytosolic distribution, whereas each $\mathrm{C} 2$ domain localizes to the plasma membrane when expressed individually (Galvez-Santisteban et al., 2012). This observation supports the idea that membrane binding by one or both $\mathrm{C} 2$ domains is required for granuphilin plasma membrane localization. Interestingly, a splice variant lacking the C2B domain, termed granuphilin-b, functions and localizes similarly to the granuphilin-a variant containing both C2 domains (Torii et al., 2004; Tsuboi and Fukuda, 2006; Wang et al., 1999).

Granuphilin functions in secretory vesicle - plasma membrane docking prior to $\mathrm{Ca}^{2+}$ triggered membrane fusion (Fukuda, 2006; Izumi, 2011). It is found in insulin-secreting pancreatic $\beta$ cells and other cell types that undergo large dense-core granule exocytosis (Bierings et al., 2012; Tomas et al., 2008; Yi et al., 2002). Altered granuphilin expression produces two seemingly contradictory effects: knockdown or knockout leads to decreased vesicle - plasma membrane docking but increased rates of secretion, while overexpression leads to increased vesicle docking with diminished secretion (Coppola et al., 2002; Gomi et al., 2005; Torii et al., 2004). This pattern suggests that granuphilin is part of an apparatus that tethers secretory vesicles to the plasma membrane and acts as a "brake" to exocytosis, which must be overcome during secretory stimulation. The molecular mechanisms of this braking behavior are unclear but likely involve syntaxin/Munc18 interaction (Gomi et al., 2005; Tsuboi and Fukuda, 2006). Importantly, the mechanism by which braking is released during active secretion is currently unknown (Izumi, 2011; Tomas et al., 2008). 
In order to better understand granuphilin-mediated secretory vesicle tethering and inhibition of membrane fusion, more information is needed on the contributions of its $\mathrm{C} 2$ domains to plasma membrane docking and release. In this study, we report docking mechanisms, target lipids, and affinities of both individual granuphilin C2 domains using a combination of equilibrium and kinetic fluorescence spectroscopy. In addition, we identify a product of insulin secretory signaling, inositol $(1,2,3,4,5,6)$-hexakisphosphate $\left(\mathrm{IP}_{6}\right)$, that displaces both $\mathrm{C} 2$ domains from lipid vesicles. The results suggest potential mechanisms by which $\mathrm{C} 2$ domains contribute significantly to granuphilin plasma membrane docking and release.

\section{Materials and Methods}

\subsection{Reagents}

Lipids were purchased from Avanti Polar Lipids (all are synthetic unless otherwise indicated): 1-palmitoyl-2-oleoyl-sn-glycero-3-phosphocholine (phosphatidylcholine, PC), 1palmitoyl-2-oleoyl-sn-glycero-3-phosphoserine (phosphatidylserine, PS), phosphatidylinositol (PI) from liver, 1-palmitoyl-2-oleoyl-sn-glycero-3phosphoethanolamine (phosphatidylethanolamine, PE), phosphatidylinositol 4,5bisphosphate $\left[\mathrm{PI}(4,5) \mathrm{P}_{2}, \mathrm{PIP}_{2}\right]$ from brain, 1,2-dioleoyl-sn-glycero-3-phospho-(1'-myoinositol-3',4',5'-trisphosphate) $\left[\mathrm{PI}(3,4,5) \mathrm{P}_{3}, \mathrm{PIP}_{3}\right]$, cholesterol, and sphingomyelin (SM) from brain. $\mathrm{N}$-[5-(dimethylamino)-naphthalene-1-sulfonyl]-1,2-dihexadecanoyl-snglycero-3-phosphoethanolamine (dansyl-PE, dPE) was from Invitrogen. D-myo-inositol 1,2,3,4,5,6,-hexakisphosphate dodecasodium salt $\left(\mathrm{IP}_{6}\right)$ was from Sigma. D-myoinositol-1,4,5-triphosphate tripotassium salt $\left(\mathrm{IP}_{3}\right)$ was from Cayman Chemical.

\subsection{Cloning, Expression and Purification of Granuphilin C2A and C2B domains}

cDNA encoding the human granuphilin C2A domain (Gly352 - Ser488) flanked by a Cterminal His 6 tag was purchased from the DNASU plasmid repository (DNASU: HsCD00321956). This domain was expressed in E. coli BL-21 cells and purified using NiNTA column chromatography. For C2B, the region of human granuphilin cDNA (ATCC: 10700678) encoding this domain (Glu487 - Leu671) was PCR-amplified and cloned into a previously described N-terminal glutathione S-transferase expression vector (Corbin et al., 2004). Protein was expressed in E. coli BL-21 cells and purified using glutathione sepharose as described (Brandt et al., 2012). High salt washes were used to remove contaminating nucleic acid, and the free $\mathrm{C} 2 \mathrm{~B}$ domain was eluted following thrombin cleavage. Purified proteins were concentrated, treated with benzonase (Sigma) for $12 \mathrm{~h}$ at $4{ }^{\circ} \mathrm{C}$ to remove remaining nucleic acid, and dialyzed into assay buffer $(140 \mathrm{mM} \mathrm{KCl}, 0.5 \mathrm{mM} \mathrm{MgCl} 2,150$ $\mathrm{mM} \mathrm{NaCl}, 25 \mathrm{mM}$ HEPES, pH 7.4) including $1 \mathrm{mM} 2$-mercaptoethanol and $0.02 \% \mathrm{NaN}_{3}$. Purity of the isolated proteins was $>95 \%$ by SDS-PAGE, and the absence of significant contaminating nucleic acid was verified via absorbance measurement at $260 \mathrm{~nm}$.

Concentration was determined from absorbance of denatured protein at $280 \mathrm{~nm}(=19940$ $\mathrm{M}^{-1} \mathrm{~cm}^{-1}$ and $34950 \mathrm{M}^{-1} \mathrm{~cm}^{-1}$ for $\mathrm{C} 2 \mathrm{~A}$ and $\mathrm{C} 2 \mathrm{~B}$, respectively).

\subsection{Preparation of Lipid Vesicles}

Small unilamellar vesicles (SUVs) with the lipid compositions listed in Table 1 were prepared by sonication as described previously (Brandt et al., 2012). 


\subsection{Equilibrium fluorescence measurements}

Measurements were performed in a Photon Technology International QuantaMaster

fluorescence spectrometer at $25^{\circ} \mathrm{C}$, with excitation at $284 \mathrm{~nm}(1 \mathrm{~nm}$ slit width) and emission slit width $8 \mathrm{~nm}$.

Qualitative protein-to-membrane FRET measurements were performed using $125 \mu \mathrm{M}$ total accessible lipid in assay buffer containing either $100 \mu \mathrm{M}$ EDTA or $1 \mathrm{mM} \mathrm{CaCl}_{2}$. First, a blank spectrum of each sample was measured in order to quantify fluorescence emission due to direct dansyl excitation at $284 \mathrm{~nm}$. Subsequent emission spectra were measured after addition of (a) $1 \mu \mathrm{M} \mathrm{C} 2 \mathrm{~A}$ or $\mathrm{C} 2 \mathrm{~B}$ domain and (b) $8 \mathrm{mM} \mathrm{IP}_{6}$. This non-physiological concentration of $\mathrm{IP}_{6}$ has been sufficient to competitively remove $\mathrm{PIP}_{\mathrm{x}}$-bound proteins in previous studies, including those with very high $\mathrm{PIP}_{\mathrm{x}}$ affinity (Kavran et al., 1998; Landgraf et al., 2008). Samples were equilibrated for $40 \mathrm{~s}$ with stirring after each addition. All spectra shown are corrected for dilution.

For measurement of $\mathrm{IP}_{6}$ or $\mathrm{IP}_{3}$ binding to the free granuphilin $\mathrm{C} 2 \mathrm{~A}$ domain $(0.2 \mu \mathrm{M})$, the change in intrinsic Trp emission at $330 \mathrm{~nm}$ was measured upon titration with ligand. (Corbin et al., 2004; Landgraf et al., 2008) Samples were equilibrated for $40 \mathrm{~s}$ with stirring following each addition, and emission intensities were averaged over $10 \mathrm{~s}$ and corrected for dilution. The resulting plot of intensity $F$ vs. ligand concentration [I] was a subject to a non-linear fit best-fit analysis in order to calculate the equilibrium dissociation constants $\left(K_{\mathrm{I}}\right)$ for these inhibitors of membrane binding:

$$
F=\Delta F_{\max }\left(\frac{[\mathrm{I}]}{K_{\mathrm{I}}+[\mathrm{I}]}\right)+C
$$

where $\Delta F_{\max }$ represents the calculated maximum fluorescence change from the unbound protein and $C$ is a constant. To simplify graphical representations, data are normalized such that $C=0$ and $\Delta F_{\max }=1$.

For FRET competition binding assays, $\mathrm{C} 2 \mathrm{~A}$ or $\mathrm{C} 2 \mathrm{~B}$ domain $(1 \mu \mathrm{M})$ was pre-mixed with liposomes (125 $\mu \mathrm{M}$ total accessible lipid) in assay buffer containing $100 \mu \mathrm{M}$ EDTA. Decreased protein-to-membrane FRET upon $\mathrm{IP}_{6}$ titration was assessed based on acceptor emission at $520 \mathrm{~nm}$, using a 10-s time average for each measurement. In a separate cuvette measured in parallel, $\mathrm{IP}_{6}$ was titrated into a sample containing lipid but no protein. After correcting for dilution, intensities from this blank sample were subtracted from the experimental samples. Resulting plots were fit to a hyperbolic model for single-site competitive inhibition:

$$
F=\Delta F_{\max }\left(1-\frac{[\mathrm{I}]}{I C_{50}+[\mathrm{I}]}\right)+C
$$

where $\Delta F_{\max }$ is the total FRET signal before ligand titration, [I] is the concentration of added $\mathrm{IP}_{6}$, and $\mathrm{IC}_{50}$ is the $\mathrm{IP}_{6}$ concentration at which FRET is $50 \%$ of the initial value. To simplify graphical representations, data are normalized such that $C=0$ and $\Delta F_{\max }=1$. 
In these competition binding measurements, equilibrium constants for protein-lipid interaction can be calculated from the best-fit $\mathrm{IC}_{50}$ value if the $K_{\mathrm{I}}$ of the inhibitor is known. Affinities measured in this manner can be expressed either as mole-fraction partition coefficients $\left(K_{\mathrm{x}}\right)$ (White and Wimley, 1999) or as $\mathrm{PIP}_{\mathrm{x}}$ dissociation constants $\left(K_{\mathrm{d}, \mathrm{PIPx}}\right)$. Here, both values are reported and are calculated using eq. 3 and 4 , respectively:

$$
\begin{gathered}
K_{\mathrm{x}}=\left(\frac{I C_{50}}{K_{\mathrm{I}}}-1\right) \times \frac{\left[\mathrm{H}_{2} \mathrm{O}\right]}{[\mathrm{L}]} \\
K_{\mathrm{d}, P I P x}=\frac{\left[P I P_{\mathrm{x}}\right] K_{\mathrm{I}}}{I C_{50}-K_{\mathrm{I}}}
\end{gathered}
$$

where [L] is the total concentration of accessible lipids in the outer leaflet (i.e., half the total lipid concentration) and $\left[\mathrm{PIP}_{\mathrm{x}}\right]$ is the concentration of free accessible $\mathrm{PI}(4,5) \mathrm{P}_{2}$ or $\mathrm{PI}(3,4,5) \mathrm{P}_{3}$ when $[\mathrm{I}]=\mathrm{IC}_{50}$ (i.e., the total outer leaflet $\left[\mathrm{PIP}_{\mathrm{x}}\right]$ less half the total protein concentration). For error propagation, the uncertainty in $[\mathrm{L}]$ or $\left[\mathrm{PIP}_{\mathrm{x}}\right]$ was estimated to be $10 \% . \mathrm{G}^{\circ}$ values are calculated as described (White and Wimley, 1999).

\subsection{Stopped-flow FRET measurement of association and dissociation kinetics}

Kinetic measurements were performed using an Applied Photophysics SX.17 stopped-flow fluorescence spectrophotometer in assay buffer with $100 \mu \mathrm{M}$ EDTA at $25^{\circ} \mathrm{C}$. Excitation was at $284 \mathrm{~nm}$ with a slit width of $3 \mathrm{~nm}$, and dansyl emission was measured using a $475-\mathrm{nm}$ longpass filter. All data prior to the instrument dead time of $1 \mathrm{~ms}$ were discarded prior to plotting and fitting.

To determine dissociation rate constants $\left(k_{\text {off }}\right)$, a solution containing protein $(0.3 \mu \mathrm{M})$ and liposomes ( $75 \mu \mathrm{M}$ total accessible lipid, concentrations after mixing) was rapidly mixed with an equal volume of a solution containing a 4-fold excess of unlabeled vesicles, which lacked dansyl-PE but were otherwise identical to the vesicles to which the protein was initially bound. Kinetic profiles of decreasing protein-to-membrane FRET were fit to singleexponential decay functions, in which the resulting approach to equilibrium is described by the intrinsic dissociation rate constant $k_{\text {off: }}$ :

$$
F=\Delta F_{\max }\left(e^{-k_{o f f} t}\right)+C
$$

For simplified presentation, the best-fit offset $C$ was subtracted from all data points and $\Delta F_{\max }$ was normalized to unity.

To determine the apparent association rate constants $\left(k_{\mathrm{obs}}\right)$ of the $\mathrm{C} 2$ domains, $\mathrm{C} 2 \mathrm{~A}$ or $\mathrm{C} 2 \mathrm{~B}$ domain $(0.3 \mu \mathrm{M})$ was rapidly mixed with liposomes $(75 \mu \mathrm{M}$ total accessible lipid, concentrations after mixing). Each resulting time course was fit to a single-exponential binding model (Corbin et al., 2004):

$$
F=\Delta F_{\max }\left(1-e^{-k_{o b s} t}\right)+C
$$


The best-fit offset $C$ was subtracted from all data points and $\Delta F_{\max }$ was normalized to unity.

The protein-membrane association rate constant $k_{\mathrm{on}}$ was calculated based on $k_{\mathrm{obs}}$ and $k_{\mathrm{off}}$ according to either the membrane partitioning $\left(k_{\mathrm{on}, \mathrm{x}}\right)$ or $\mathrm{PI}(4,5) \mathrm{P}_{2}$ binding $\left(k_{\mathrm{On}, \mathrm{PIP} 2}\right)$ model using eq. 7 or 8 , respectively:

$$
\begin{gathered}
k_{o n, \mathrm{x}}=\left(k_{o b s}-k_{o f f}\right) \times \frac{\left[\mathrm{H}_{2} \mathrm{O}\right]}{[\mathrm{L}]} \\
k_{o n, P I P 2}=\frac{k_{o b s}-k_{o f f}}{\left[P I P_{2}\right]}
\end{gathered}
$$

where $[\mathrm{L}]$ is the total outer leaflet lipid concentration and $\left[\mathrm{PIP}_{2}\right]$ is the concentration of unbound $\mathrm{PI}(4,5) \mathrm{P}_{2}$ in the outer leaflet, approximated as the total outer leaflet $\mathrm{PI}(4,5) \mathrm{P}_{2}$ concentration less half the total protein concentration.

\subsection{Electrostatic surface calculations for $\mathrm{C} 2 \mathrm{~A}$}

Electrostatic surface calculations were based on the available structure of granuphilin $\mathrm{C} 2 \mathrm{~A}$ (PDB: 3FDW). The positions of missing atoms in the structure (some sidechain atoms from K365, Q369, T370, K390, K391, R407, S435, Q439, D466, K469, and K483) were modeled using default settings of Swiss PDB Viewer. The electrostatic surface was generated using the Advanced Poisson-Boltzmann Solver plugin (APBS 0.5.1) for PyMol, with calculations performed using $0.15 \mathrm{M}$ monovalent cation and anion concentrations.

\section{Results}

\subsection{Identification of target lipids using protein-to-membrane FRET}

In order to measure the lipid composition dependence of membrane targeting for granuphilin C2 domains, an established protein-to-membrane fluorescence resonance energy transfer (FRET) assay was used with SUVs of defined lipid composition (Nalefski and Falke, 2002). In this measurement, one or more Trp residues intrinsic to the protein domain ( 2 total in C2A, 5 in C2B) serve as FRET donors, and dansyl-phosphatidylethanolamine (dPE) lipids included in the liposomes serve as FRET acceptors. Protein-membrane binding leads to an increased dPE emission at $512 \mathrm{~nm}$ upon Trp excitation at $284 \mathrm{~nm}$ and a decrease in Trp emission at $350 \mathrm{~nm}$. In order to determine target lipid preferences for granuphilin $\mathrm{C} 2 \mathrm{~A}$ and C2B domains, liposomes were prepared with the compositions listed in Table 1.

The granuphilin C2A domain shows significant protein-to-membrane FRET when added to liposomes closely resembling the lipid composition of the plasma membrane cytosolic leaflet (Corbin et al., 2007; Voelker, 2008). Since some C2 domains are known to dock preferentially to $\mathrm{PIP}_{\mathrm{X}}$ lipids, such physiologically relevant lipid mixtures are used throughout this study either including $2 \% \mathrm{PI}(4,5) \mathrm{P}_{2}\left[\mathrm{PM}(+) 2 \% \mathrm{PIP}_{2}\right]$ or lacking $\mathrm{PIP}_{\mathrm{X}}$ $\left[\mathrm{PM}(-) \mathrm{PIP}_{\mathrm{X}}\right]$. In qualitative measurements, addition of the $\mathrm{C} 2 \mathrm{~A}$ domain led to an increase in dPE emission in vesicles with either of these compositions (Figure 1A,B), but not vesicles composed only of phosphatidylcholine (PC) and dPE (Figure 1C).

Chem Phys Lipids. Author manuscript; available in PMC 2015 September 01. 
In order to identify the lipid components responsible for $\mathrm{C} 2 \mathrm{~A}$ association with $\mathrm{PM}(-) \mathrm{PIP}_{\mathrm{x}}$ vesicles, simpler lipid compositions were tested. FRET was observed upon addition of $\mathrm{C} 2 \mathrm{~A}$ to vesicles containing the anionic background lipids phosphatidylserine (PS) and phosphatidylinositol (PI) along with PC (Figure 2A), but not to vesicles containing only the zwitterionic components of our PM(-)PIP $\mathrm{P}_{\mathrm{x}}$ mixture (Figure 2B). Binding was restored upon replacement of PS and PI with phosphatidylglycerol (PG), an anionic lipid that is not normally present in mammalian plasma membranes (van Meer et al., 2008) (Supplementary data, Figure S1), suggesting that $\mathrm{C} 2 \mathrm{~A}$ binds anionic background lipids such as these through nonspecific interactions.

In contrast to $\mathrm{C} 2 \mathrm{~A}$, no FRET was observed upon addition of $1 \mu \mathrm{M} \mathrm{C} 2 \mathrm{~B}$ domain to $\mathrm{PM}(-) \mathrm{PIP}_{\mathrm{x}}$, indicating binding is too weak to measure with this lipid composition (Figure $3 \mathrm{~A})$. However, significant interaction was observed when $\mathrm{PI}(4,5) \mathrm{P}_{2}$ was included in the liposomes (Figure 3B). For both domains, the FRET efficiency was identical whether measured in the presence of $100 \mu \mathrm{M}$ EDTA or $1 \mathrm{mM} \mathrm{Ca}^{2+}$ (data not shown), consistent with previous reports that granuphilin $\mathrm{C} 2$ domains bind anionic lipids in a $\mathrm{Ca}^{2+}$-independent manner (Wang et al., 1999; Yu et al., 2007).

$\mathrm{IP}_{6}$ inhibits lipid binding by both granuphilin $\mathrm{C} 2$ domains. $\mathrm{IP}_{6}$ is a soluble, fully phosphorylated analogue of $\mathrm{PIP}_{\mathrm{x}}$ lipid headgroups, which competitively inhibits membrane binding by protein domains that target PIP $_{\mathrm{x}}$ lipids (Corbin et al., 2004; Landgraf et al., 2008; Takeuchi et al., 1997). For both granuphilin C2 domains and with all lipid compositions tested, protein-to-membrane FRET was completely reversed by the addition of $8 \mathrm{mM} \mathrm{IP}_{6}$ as judged by dansyl emission at $512 \mathrm{~nm}$ (Figures 1-3). $\mathrm{IP}_{6}$ addition also resulted in a measurable increase in the intrinsic Trp emission of the $\mathrm{C} 2 \mathrm{~A}$ domain even in the absence of membrane binding (Figure 1C), an effect that was not observed for C2B. Such a Trp fluorescence increase has been previously observed with PIP $_{\mathrm{x}}$-binding pleckstrin homology domains (Corbin et al., 2004; Landgraf et al., 2008) and may be due to a change in the microenvironment around one or both of the Trp residues in granuphilin C2A upon binding $\mathrm{IP}_{6}$.

\subsection{Quantifying $\mathrm{C} 2 \mathrm{~A}$ affinity for $\mathrm{IP}_{6}$ and $\mathrm{IP}_{3}$}

Qualitative measurements such as those shown in Figures 1-3 do not distinguish between tight and moderate lipid binding affinities, as any interaction in the micromolar range or tighter produces nearly complete binding. However, the lipid affinity of a tightly bound protein can be determined quantitatively using a competitive binding assay if an inhibitor is available with known affinity for the protein (Corbin et al., 2004). Thus, the affinity of C2A for $\mathrm{IP}_{6}$ was first measured based on the intrinsic Trp fluorescence increase, in order that this domain's affinity for target vesicles could be subsequently quantified. $\mathrm{IP}_{6}$ titration data fit well to a single-site binding model with an inhibitor equilibrium dissociation constant $\left(K_{\mathrm{I}}\right)$ of $1.8 \pm 0.1 \mu \mathrm{M}$ (Figure 4A). Similar measurement of $\mathrm{C} 2 \mathrm{~A}$ affinity for $\mathrm{IP}_{3}$ reveals considerably weaker binding, with a $K_{\mathrm{I}}$ of $80 \pm 30 \mu \mathrm{M}$ (Figure 4B). This difference stands in contrast to the pleckstrin homology domain from phospholipase $\mathrm{C}-\delta_{1}$, which binds preferentially to $\mathrm{PI}(4,5) \mathrm{P}_{2}$ over other $\mathrm{PIP}_{\mathrm{x}}$ species and exhibits a higher affinity towards $\mathrm{IP}_{3}$ 
compared to $\mathrm{IP}_{6}$ (Kavran et al., 1998). For the present study, the higher-affinity inhibitor $\mathrm{IP}_{6}$ was used for subsequent competition experiments.

\subsection{C2A competition binding measurements}

Competition binding measurements with $\mathrm{IP}_{6}$ show that $\mathrm{PI}(4,5) \mathrm{P}_{2}$ enhances the affinity of granuphilin C2A for liposomes $\sim 40$-fold. As shown in Figure 5A and summarized in Table $2, \mathrm{IP}_{6}$ was titrated into solutions containing $\mathrm{C} 2 \mathrm{~A}$ domain bound to vesicles. A simple competitive inhibition model is sufficient to describe the $\mathrm{IP}_{6}$ titration data. The inhibitor concentration at which the amount of vesicle-bound protein was half its initial value $\left(\mathrm{IC}_{50}\right)$ increased from $37 \pm 6 \mu \mathrm{M}$ to $1.6 \pm 0.2 \mathrm{mM}$ upon inclusion of $2 \% \mathrm{PI}(4,5) \mathrm{P}_{2}$ (Table 2). These data, together with the measured affinity of $\mathrm{C}_{2} \mathrm{~A}$ for $\mathrm{IP}_{6}$ (Figure $4 \mathrm{~A}$ ), can be used to calculate a mole-fraction partition coefficient, $K_{\mathrm{X}}$, describing the liposomal membrane partitioning equilibrium for each lipid composition (White and Wimley, 1999). This value is $(9 \pm 2) \times 10^{6}$ for $\mathrm{PM}(-) \mathrm{PIP}_{\mathrm{x}}$ vesicles and increases $\sim 40$-fold to $(390 \pm 70) \times 10^{6}$ for

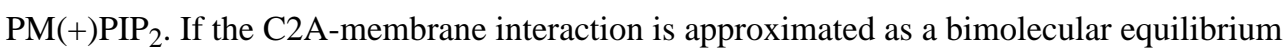
between the protein and $\mathrm{PI}(4,5) \mathrm{P}_{2}$ headgroups rather than a membrane/aqueous phase partitioning, the same data yield an apparent equilibrium dissociation constant, $K_{\mathrm{d}, \mathrm{PIP} 2}$, of $2.3 \pm 0.4 \mathrm{nM}$ (Table 2). Replacement of $\mathrm{PI}(4,5) \mathrm{P}_{2}$ with $2 \% \mathrm{PI}(3,4,5) \mathrm{P}_{3}$ in target liposomes leads to similarly tight binding, with an affinity that differs from $\mathrm{PM}(+) \mathrm{PIP}_{2}$ vesicles by less than a factor of two (Table 2). This result is consistent with earlier reports of low $\operatorname{PIP}_{x}$ selectivity by this domain using less quantitative methods (Galvez-Santisteban et al., 2012; Wang et al., 2013). Overall, it is clear that granuphilin C2A binds with high affinity to liposomes containing physiological mixtures of background anionic lipids and either $\mathrm{PI}(4,5) \mathrm{P}_{2}$ or $\mathrm{PI}(3,4,5) \mathrm{P}_{3}$.

In order to quantitatively test for specificity in $\mathrm{C} 2 \mathrm{~A}$ interactions with background anionic lipids, $\mathrm{IP}_{6}$ competition titrations were conducted with this domain and simple 3:1 lipid mixtures of PC and either PS, PI, or PG. These titrations reveal similar affinities of the C2A domain for these three simple lipid compositions, indicating that interactions with background anionic lipids are nonspecific (Supplementary data, Figure S2). $K_{\mathrm{X}}$ values for these lipid compositions range from $8 \times 10^{5}$ to $2 \times 10^{6}$, lower by factors of 4-10 than for $\mathrm{PM}(-) \mathrm{PIP}_{\mathrm{x}}$ (Table 2). Such lower affinity for simple lipid mixtures versus physiological mixtures with similar anionic content has also been observed for other PIP $_{\mathrm{x}}$-targeting domains, although the underlying reasons for this effect are not clear (Corbin et al., 2004).

$\mathrm{IP}_{6}$ also competes with the $\mathrm{C} 2 \mathrm{~B}$ domain for lipid binding, with an $\mathrm{IC}_{50}$ of $21 \pm 3 \mu \mathrm{M}$ (Figure $5 \mathrm{~B}$, Table 2). $\mathrm{IP}_{6}$ binding does not significantly alter the intrinsic Trp fluorescence of $\mathrm{C} 2 \mathrm{~B}$ (data not shown), preventing direct measurement of $\mathrm{C} 2 \mathrm{~B}-\mathrm{IP}_{6}$ affinity using this approach.

\subsection{Kinetics of membrane association and dissociation}

FRET-based kinetic measurements of protein-lipid association and dissociation further demonstrate high-affinity binding. Stopped-flow association measurements (Figure 6A) generally fit well to single-exponential profiles with rate constants $\left(k_{\text {obs }}\right)$ listed in Table 3. Rates of stochastic dissociation were measured by rapidly mixing protein-membrane complexes with an excess of unlabeled liposomes (Figure 6B). The decay constant of the 
resulting approach to equilibrium is equivalent to the rate constant for protein-membrane dissociation, $k_{\text {off }}$; these values are listed in Table 3 .

The observed association rate constant, $k_{\mathrm{obs}}$, is related to the intrinsic association and dissociation rate constants, $k_{\text {on }}$ and $k_{\text {off }}$, via eq. 7 (if the interaction is modeled as a phase partitioning) or eq. 8 (if the interaction is modeled as a bimolecular binding equilibrium). The ratios of these rate constants for $\mathrm{C} 2 \mathrm{~A}$ interacting with both $\mathrm{PM}(+) \mathrm{PIP}_{2}$ and $\mathrm{PM}(-) \mathrm{PIP}_{\mathrm{x}}$ vesicles agree within a factor of two of the respective equilibrium constants $\left(K_{\mathrm{X}}\right.$ and $\left.K_{\mathrm{d} \text {,PIP2 }}\right)$ measured using the $\mathrm{IP}_{6}$ competition assay (Tables 2-3). Kinetic measurements with the $\mathrm{C} 2 \mathrm{~B}$ domain suggest a $\sim 50$-fold weaker interaction relative to $\mathrm{C} 2 \mathrm{~A}$ with $\mathrm{PM}(+) \mathrm{PIP}_{2}$, due to a $\sim 15$-fold faster $k_{\text {off }}$ and a $\sim 3$-fold slower $k_{\text {on }}$ (Figure 6 , Table 3). Overall, these two complementary approaches demonstrate a high-affinity interaction between the $\mathrm{C} 2 \mathrm{~A}$ domain and vesicles containing $\mathrm{PI}(4,5) \mathrm{P}_{2}$ and background anionic lipids.

\section{Discussion}

$\mathrm{C} 2$ domains are essential components of regulated exocytosis. Deletion of both $\mathrm{C} 2$ domains from granuphilin has been shown to produce localization in the cytosol or on vesicles rather than on the plasma membrane, as well as reduced vesicle-plasma membrane docking (Galvez-Santisteban et al., 2012; Tsuboi and Fukuda, 2006), suggesting that these domains play a key role in granuphilin plasma membrane targeting. Here we report the following new observations for $\mathrm{C} 2$ domain interaction with artificial vesicles composed of physiological lipid mixtures: (i) granuphilin $\mathrm{C} 2 \mathrm{~A}$ binds strongly to vesicles containing $\mathrm{PI}(4,5) \mathrm{P}_{2}$ or $\mathrm{PI}(3,4,5) \mathrm{P}_{3}$ and the background anionic lipids PS and PI, with apparent $\mathrm{PIP}_{\mathrm{x}}$ affinities in the 2-5 $\mathrm{nM}$ range; (ii) $\mathrm{C} 2 \mathrm{~A}$ binds $~ 40$-fold less strongly to otherwise identical vesicles lacking $\mathrm{PIP}_{\mathrm{x}}$; (iii) $\mathrm{C} 2 \mathrm{~B}$ interacts with vesicles containing $\mathrm{PI}(4,5) \mathrm{P}_{2}$ with sub-micromolar affinity, but not with vesicles lacking $\mathrm{PIP}_{\mathrm{x}}$; and (iv) $\mathrm{IP}_{6}$ binds with low micromolar affinity and competes with lipid binding for both domains.

The granuphilin $\mathrm{C} 2 \mathrm{~A}$ domain interacts nonspecifically with monoanionic background lipids including PS, PI, and PG, and binds with much stronger affinity to vesicles that include polyanionic lipids such as $\mathrm{PI}(4,5) \mathrm{P}_{2}$ or $\mathrm{PI}(3,4,5) \mathrm{P}_{3}$ (Table 2). Furthermore, this domain binds $\mathrm{IP}_{3} \sim 40$-fold less tightly than the more anionic $\mathrm{IP}_{6}$. Granuphilin $\mathrm{C} 2 \mathrm{~A}$ possesses a net charge near +8 at neutral $\mathrm{pH}$ (Olsson et al., 2011), and these observations suggest that electrostatics may play a dominant role in $\operatorname{IP}_{\mathrm{x}}$ and $\mathrm{PIP}_{\mathrm{x}}$ binding. Our results indicate that this domain binds $\mathrm{PI}(4,5) \mathrm{P}_{2}$ and $\mathrm{PI}(3,4,5) \mathrm{P}_{3}$ with similar affinity, and a previous study using immobilized lipids also showed little PIP $\mathrm{P}_{\mathrm{x}}$ selectivity for both $\mathrm{C} 2 \mathrm{~A}$ and $\mathrm{C} 2 \mathrm{~B}$ (GalvezSantisteban et al., 2012). It has been suggested that promiscuous PIP $_{\mathrm{x}}$-binding domains are likely regulated by the most abundant PIP $_{\mathrm{x}}$ species in their target membrane (Kavran et al., 1998). Granuphilin targets the plasma membrane, in part through interaction of its linker domain with Munc18/syntaxin (Tsuboi and Fukuda, 2006), and PI(4,5) $\mathrm{P}_{2}$ is the most abundant PIP $_{\mathrm{x}}$ species in this compartment (Balla, 2005; Di Paolo and De Camilli, 2006; Lemmon, 2008). Our data suggest that $\mathrm{C} 2$ domain lipid binding may provide a significant contribution to the affinity of this protein's membrane interaction. 
Available structural data for $\mathrm{C} 2 \mathrm{~A}$ are consistent with membrane binding via electrostatic interaction with PIP $_{\mathrm{X}}$ and background anionic lipids via one or more binding sites. PoissonBoltzmann mapping reveals a large positively charged surface on this domain (Figure 7). This surface includes a canonical $\mathrm{PIP}_{\mathrm{X}}$ binding motif, $\mathrm{K}(\mathrm{K} / \mathrm{R}) \mathrm{KTXXK}(\mathrm{K} / \mathrm{R})$, homologous to synaptotagmin 1 C2B (Figure 7, black arrow) (Galvez-Santisteban et al., 2012) as well as a cleft composed of basic residues in the $\beta 2-\beta 3$ and $\beta 6-\beta 7$ loops (Figure 7 , green arrow). The latter cleft is equivalent to the $\mathrm{Ca}^{2+}$ binding site of synaptotagmin $\mathrm{C} 2$ domains, but granuphilin $\mathrm{C} 2 \mathrm{~A}$ contains only one of the five $\mathrm{Ca}^{2+}$-chelating Asp residues conserved among synaptotagmin isoforms (Bhalla et al., 2008). Further studies are needed to discern which site(s) on this domain are involved in binding lipids and/or $\mathrm{IP}_{6}$.

Equilibrium fluorescence data for $\mathrm{C} 2 \mathrm{~A}-\mathrm{IP}_{6}$ binding and competition with lipids both fit well to simple hyperbolic functions, suggesting that $\mathrm{IP}_{6}$ binds this domain at a single site and thereby blocks lipid interaction. Our data are consistent with the presence of one or more lipid binding sites, provided a single bound $\mathrm{IP}_{6}$ is sufficient to displace the domain from the membrane. This assertion seems reasonable from an electrostatic standpoint, as binding of one $\mathrm{IP}_{6}$ molecule should neutralize the net charge of the $\mathrm{C} 2 \mathrm{~A}$ domain and disrupt nonspecific electrostatic interactions. However, membrane interaction involving multiple lipid ligands may not be represented appropriately by a bimolecular dissociation equilibrium constant $\left(K_{\mathrm{d}, \mathrm{PIPx}}\right)$. Therefore, we also report mole fraction partition coefficients $\left(K_{\mathrm{X}}\right)$, which do not assume protein lipid binding stoichiometry, in addition to the more familiar $K_{\mathrm{d}}$. Both measured values reflect high-affinity association of C2A with $\mathrm{PM}(+) \mathrm{PIP}_{2}$ and $\mathrm{PM}(+) \mathrm{PIP}_{3}$ vesicles, and correspond to $\mathrm{G}^{\circ}$ values for binding of approximately $-12 \mathrm{kcal} / \mathrm{mol}$ (Table 2 ).

Strong interaction is further supported by kinetic measurements of protein-lipid association and dissociation. The ratios of measured rate constants for $\mathrm{C} 2 \mathrm{~A}$ association with both $\mathrm{PM}(+) \mathrm{PIP}_{2}$ and $\mathrm{PM}(-) \mathrm{PIP}_{\mathrm{X}}$ vesicles are in close agreement with the affinities reported from equilibrium competition measurements. The single-exponential kinetic profiles indicate that membrane association and dissociation for both domains likely proceed via a single ratelimiting step, but do not report on stoichiometry of lipid interaction. Notably, the dissociation rate constant of $0.48 \mathrm{~s}^{-1}$ for $\mathrm{C} 2 \mathrm{~A}$ is extremely slow for a membrane-targeting C2 domain, consistent with its high affinity (Brandt et al., 2012; Corbin et al., 2007; Hui et al., 2005; Nalefski et al., 1997). Interestingly, when we attempted to measure membrane dissociation by rapidly adding high concentrations of $\operatorname{IP}_{6}(8 \mathrm{mM})$, an approach used with other PIP ${ }_{\mathrm{x}}$-binding domains (Corbin et al., 2004; Knight and Falke, 2009), dissociation kinetics were biexponential and $\sim 100$-fold faster than those measured by the approach to equilibrium method (Supplementary data, Figure S3). The origins of this difference are currently under investigation; however, the good agreement between our $\mathrm{IP}_{6}$-independent kinetic measurements (Table 3 ) and equilibrium $\mathrm{IP}_{6}$ competition measurements (Table 2) suggests that high concentrations of $\mathrm{IP}_{6}$ may alter the kinetic pathway of dissociation without affecting the equilibrium thermodynamics of the system.

While affinity of $\mathrm{C} 2 \mathrm{~B}$ for $\mathrm{PM}(+) \mathrm{PIP}_{2}$ vesicles cannot be calculated from our equilibrium competition measurements due to lack of a direct fluorescent reporter for $\mathrm{C} 2 \mathrm{~B}-\mathrm{IP}_{6}$ binding, the equilibrium constant can be calculated from kinetic parameters. The measured $k_{\text {off }} / k_{\text {on }}$ ratio yields an apparent $K_{\mathrm{d}, \mathrm{PIP} 2}$ of $200 \pm 40 \mathrm{nM}$, weaker than C2A but still significantly 
strong for a domain that is tethered in close proximity to target lipids (Shao et al., 2008). Previous studies have shown that splice variants of granuphilin with and without the C2B domain exhibit similar cellular behavior; however, the presence of this domain could conceivably modulate sensitivity to target lipids or $\mathrm{IP}_{\mathrm{x}}$ species that may regulate membrane binding in vivo (Torii et al., 2004; Tsuboi and Fukuda, 2006). Intriguingly, substitution of $k_{\text {off }} / k_{\text {on }}$ in the place of $K_{\mathrm{d} \text {,PIP2 } 2}$ in eq. 4 yields an equilibrium constant for C2B $-\mathrm{IP}_{6}$ interaction of $1.9 \pm 0.5 \mu \mathrm{M}$, remarkably similar to the $K_{\mathrm{I}}$ of $1.8 \pm 0.1 \mu \mathrm{M}$ measured directly for $\mathrm{C} 2 \mathrm{~A}$. Further studies are needed to clarify the potential role(s) of $\mathrm{IP}_{3}$ and $\mathrm{IP}_{6}$ binding to $\mathrm{C} 2 \mathrm{~A}$ and $\mathrm{C} 2 \mathrm{~B}$ in granuphilin function.

Finally, the competitive removal of granuphilin $\mathrm{C} 2$ domain-lipid binding by $\mathrm{IP}_{6}$ suggests a possible mechanism of granuphilin release from the plasma membrane during exocytosis. $\mathrm{IP}_{6}$ concentrations in insulin-secreting cells increase from $\sim 40 \mu \mathrm{M}$ to $\sim 60 \mu \mathrm{M}$ during exocytosis (Berggren and Barker, 2008; Larsson et al., 1997; Li et al., 1992). While our data suggest these concentrations are insufficient to remove $\mathrm{C} 2 \mathrm{~A}$ from membranes containing $\mathrm{PI}(4,5) \mathrm{P}_{2}$, the presence of $40-60 \mu \mathrm{M} \mathrm{IP}_{6}$ [along with possibly other $\mathrm{IP}_{\mathrm{x}}$ species (Illies et al., 2007)] could potentially compete with $C 2 B-$ membrane binding and $C 2 A$ binding to PIP $_{x^{-}}$ free membranes. Thus, it is possible that granuphilin $\mathrm{C} 2$ domains could be removed from their target lipids during insulin secretion by simultaneous increases in cellular $\mathrm{IP}_{\mathrm{x}}$ production and localized decreases in membrane $\mathrm{PI}(4,5) \mathrm{P}_{2}$ content due to phospholipase $\mathrm{C}$ (PLC) activation (Efanov et al., 1997; Thore et al., 2007). The generation of $\mathrm{IP}_{3}$ by PLC would also contribute to this dissociation, although $\mathrm{IP}_{3}$ binds $\mathrm{C} 2 \mathrm{~A}$ less tightly than $\mathrm{IP}_{6}$. As noted previously, deletion of both $\mathrm{C} 2$ domains results in the loss of both plasma membrane localization and inhibitory activity, suggesting that interaction with Munc18/syntaxin alone is insufficient for proper localization (Galvez-Santisteban et al., 2012; Tsuboi and Fukuda, 2006). Thus, it is feasible that signaling-induced dissociation of these $C 2$ domains from the plasma membrane could facilitate release from protein binding partners and removal of the "brake" on exocytosis. Clearly, further studies in secretory systems are needed in order to test these hypotheses and further define the roles of granuphilin C2 domains in secretory vesicle docking and fusion.

\section{Supplementary Material}

Refer to Web version on PubMed Central for supplementary material.

\section{Acknowledgments}

The authors thank DNASU for providing a plasmid for expression of granuphilin C2A and Dr. John Corbin for critical reading of this manuscript. T.A.L. was supported by a fellowship through the CU Denver LABCOATS program (NIH 5R25GM083333 to Prof. Sonia Flores), a fellowship from the CU Denver Undergraduate Research Opportunity Program, and a scholarship from the Beta Beta Beta Research Foundation.

\section{Abbreviations}

C2 domain domain with homology to the second conserved region of protein kinase C 


$\begin{array}{ll}\text { PI(4,5) } \mathbf{P}_{\mathbf{2}} \text { or PIP } & \text { phosphatidylinositol-(4,5)-bisphosphate } \\ \mathbf{P I}(\mathbf{3 , 4 , 5}) \mathbf{P}_{\mathbf{3}} \text { or PIP } & \text { phosphatidylinositol-(3,4,5)-trisphosphate } \\ \text { PS } & \text { phosphatidylserine } \\ \text { PI } & \text { phosphatidylinositol } \\ \text { PC } & \text { phosphatidylcholine } \\ \text { PE } & \text { phosphatidylethanolamine } \\ \text { PG } & \text { phosphatidylglycerol } \\ \text { SM } & \text { sphingomyelin } \\ \text { CH } & \text { cholesterol } \\ \text { dPE or dansyl-PE } & \text { dansyl phosphatidylethanolamine } \\ \text { PIP } & \text { phosphatidylinositol phosphate } \\ \text { IP } & \text { inositol-(1,2,3,4,5,6)-hexakisphosphate } \\ \text { IP } & \text { inositol-(1,4,5)-trisphosphate } \\ \text { IP } & \text { inositol polyphosphate } \\ \text { Slp } & \text { synaptotagmin-like protein } \\ \text { EDTA } & \text { ethylenediamine tetraacetic acid } \\ \text { FRET } & \text { fluorescence resonance energy transfer } \\ \text { SUV } & \text { small unilamellar vesicle }\end{array}$

\section{References}

Balla T. Inositol-lipid binding motifs: signal integrators through protein-lipid and protein-protein interactions. J Cell Sci. 2005; 118:2093-2104. [PubMed: 15890985]

Berggren PO, Barker CJ. A key role for phosphorylated inositol compounds in pancreatic beta- cell stimulus-secretion coupling. Adv Enzyme Regul. 2008; 48:276-294. [PubMed: 18194673]

Bhalla A, Chicka MC, Chapman ER. Analysis of the synaptotagmin family during reconstituted membrane fusion. Uncovering a class of inhibitory isoforms. J Biol Chem. 2008; 283:21799-21807. [PubMed: 18508778]

Bierings R, Hellen N, Kiskin N, Knipe L, Fonseca AV, Patel B, Meli A, Rose M, Hannah MJ, Carter T. The interplay between the Rab27A effectors Slp4-a and MyRIP controls hormone- evoked Weibel-Palade body exocytosis. Blood. 2012; 120:2757-2767. [PubMed: 22898601]

Brandt DS, Coffman MD, Falke JJ, Knight JD. Hydrophobic contributions to the membrane docking of synaptotagmin $7 \mathrm{C} 2 \mathrm{~A}$ domain: mechanistic contrast between isoforms 1 and 7 . Biochemistry. 2012; 51:7654-7664. [PubMed: 22966849]

Cho W, Stahelin RV. Membrane-protein interactions in cell signaling and membrane trafficking. Annu Rev Biophys Biomol Struct. 2005; 34:119-151. [PubMed: 15869386]

Coppola T, Frantz C, Perret-Menoud V, Gattesco S, Hirling H, Regazzi R. Pancreatic beta-cell protein granuphilin binds Rab3 and Munc-18 and controls exocytosis. Mol Biol Cell. 2002; 13:1906-1915. [PubMed: 12058058]

Corbalan-Garcia S, Garcia-Garcia J, Rodriguez-Alfaro JA, Gomez-Fernandez JC. A new phosphatidylinositol 4,5-bisphosphate-binding site located in the $\mathrm{C} 2$ domain of protein kinase $\mathrm{C}$. $\mathrm{J}$ Biol Chem. 2003; 278:4972-4980. [PubMed: 12426311] 
Corbin JA, Dirkx RA, Falke JJ. GRP1 pleckstrin homology domain: Activation parameters and novel search mechanism for rare target lipid. Biochemistry. 2004; 43:16161-16173. [PubMed: 15610010]

Corbin JA, Evans JH, Landgraf KE, Falke JJ. Mechanism of specific membrane targeting by C2 domains: Localized pools of target lipids enhance $\mathrm{Ca}^{2+}$ affinity. Biochemistry. 2007; 46:43224336. [PubMed: 17367165]

Di Paolo G, De Camilli P. Phosphoinositides in cell regulation and membrane dynamics. Nature. 2006; 443:651-657. [PubMed: 17035995]

Efanov AM, Zaitsev SV, Berggren PO. Inositol hexakisphosphate stimulates non- $\mathrm{Ca}^{2+-}$ mediated and primes $\mathrm{Ca}^{2+}$-mediated exocytosis of insulin by activation of protein kinase C. Proc Natl Acad Sci U S A. 1997; 94:4435-4439. [PubMed: 9114007]

Fukuda M. Rab27 and its effectors in secretory granule exocytosis: a novel docking machinery composed of a Rab27.effector complex. Biochem Soc Trans. 2006; 34:691-695. [PubMed: 17052176]

Fukuda M, Mikoshiba K. Synaptotagmin-like protein 1-3: a novel family of C-terminal-type tandem C2 proteins. Biochem Biophys Res Commun. 2001; 281:1226-1233. [PubMed: 11243866]

Galvez-Santisteban M, Rodriguez-Fraticelli AE, Bryant DM, Vergarajauregui S, Yasuda T, BanonRodriguez I, Bernascone I, Datta A, Spivak N, Young K, Slim CL, Brakeman PR, Fukuda M, Mostov KE, Martin-Belmonte F. Synaptotagmin-like proteins control the formation of a single apical membrane domain in epithelial cells. Nat Cell Biol. 2012; 14:838-849. [PubMed: 22820376]

Gomi H, Mizutani S, Kasai K, Itohara S, Izumi T. Granuphilin molecularly docks insulin granules to the fusion machinery. J Cell Biol. 2005; 171:99-109. [PubMed: 16216924]

Gustavsson N, Han W. Calcium-sensing beyond neurotransmitters: functions of synaptotagmins in neuroendocrine and endocrine secretion. Biosci Rep. 2009; 29:245-259. [PubMed: 19500075]

Hui E, Bai J, Wang P, Sugimori M, Llinas RR, Chapman ER. Three distinct kinetic groupings of the synaptotagmin family: candidate sensors for rapid and delayed exocytosis. Proc Natl Acad Sci U S A. 2005; 102:5210-5214. [PubMed: 15793006]

Illies C, Gromada J, Fiume R, Leibiger B, Yu J, Juhl K, Yang SN, Barma DK, Falck JR, Saiardi A, Barker CJ, Berggren PO. Requirement of inositol pyrophosphates for full exocytotic capacity in pancreatic beta cells. Science. 2007; 318:1299-1302. [PubMed: 18033884]

Izumi T. Heterogeneous modes of insulin granule exocytosis: molecular determinants. Front Biosci. $2011 ; 16: 360-367$.

Kavran JM, Klein DE, Lee A, Falasca M, Isakoff SJ, Skolnik EY, Lemmon MA. Specificity and promiscuity in phosphoinositide binding by pleckstrin homology domains. J Biol Chem. 1998; 273:30497-30508. [PubMed: 9804818]

Knight JD, Falke JJ. Single-molecule fluorescence studies of a PH domain: new insights into the membrane docking reaction. Biophys J. 2009; 96:566-582. [PubMed: 19167305]

Landgraf KE, Pilling C, Falke JJ. Molecular mechanism of an oncogenic mutation that alters membrane targeting: Glu17Lys modifies the PIP lipid specificity of the AKT1 PH domain. Biochemistry. 2008; 47:12260-12269. [PubMed: 18954143]

Larsson O, Barker CJ, Sjoholm A, Carlqvist H, Michell RH, Bertorello A, Nilsson T, Honkanen RE, Mayr GW, Zwiller J, Berggren PO. Inhibition of phosphatases and increased $\mathrm{Ca}^{2+}$ channel activity by inositol hexakisphosphate. Science. 1997; 278:471-474. [PubMed: 9334307]

Lemmon MA. Membrane recognition by phospholipid-binding domains. Nat Rev Mol Cell Biol. 2008; 9:99-111. [PubMed: 18216767]

Li G, Pralong WF, Pittet D, Mayr GW, Schlegel W, Wollheim CB. Inositol tetrakisphosphate isomers and elevation of cytosolic $\mathrm{Ca}^{2+}$ in vasopressin-stimulated insulin-secreting RINm5F cells. J Biol Chem. 1992; 267:4349-4356. [PubMed: 1311307]

Martens S. Role of C2 domain proteins during synaptic vesicle exocytosis. Biochem Soc Trans. 2010; 38:213-216. [PubMed: 20074062]

Murray D, Honig B. Electrostatic control of the membrane targeting of C2 domains. Mol Cell. 2002; 9:145-154. [PubMed: 11804593]

Nalefski EA, Falke JJ. The C2 domain calcium-binding motif: structural and functional diversity. Protein Sci. 1996; 5:2375-2390. [PubMed: 8976547] 
Nalefski EA, Falke JJ. Use of fluorescence resonance energy transfer to monitor $\mathrm{Ca}^{2+}$-triggered membrane docking of C2 domains. Methods Mol Biol. 2002; 172:295-303. [PubMed: 11833355]

Nalefski EA, Slazas MM, Falke JJ. $\mathrm{Ca}^{2+}$-signaling cycle of a membrane-docking C2 domain. Biochemistry. 1997; 36:12011-12018. [PubMed: 9340010]

Olsson MHM, Sondergaard CR, Rostkowski M, Jensen JH. PROPKA3: Consistent Treatment of Internal and Surface Residues in Empirical $\mathrm{pK}_{\mathrm{a}}$ Predictions. J. Chem. Theory Comput. 2011; 7:525-537.

Radhakrishnan A, Stein A, Jahn R, Fasshauer D. The $\mathrm{Ca}^{2+}$ affinity of synaptotagmin 1 is markedly increased by a specific interaction of its $\mathrm{C} 2 \mathrm{~B}$ domain with phosphatidylinositol 4,5- bisphosphate. J Biol Chem. 2009; 284:25749-25760. [PubMed: 19632983]

Shao C, Novakovic VA, Head JF, Seaton BA, Gilbert GE. Crystal structure of lactadherin C2 domain at $1.7 \AA$ resolution with mutational and computational analyses of its membrane-binding motif. J Biol Chem. 2008; 283:7230-7241. [PubMed: 18160406]

Sudhof TC. Synaptotagmins: why so many? J Biol Chem. 2002; 277:7629-7632. [PubMed: 11739399]

Takeuchi H, Kanematsu T, Misumi Y, Sakane F, Konishi H, Kikkawa U, Watanabe Y, Katan M, Hirata M. Distinct specificity in the binding of inositol phosphates by pleckstrin homology domains of pleckstrin, RAC-protein kinase, diacylglycerol kinase and a new $130 \mathrm{kDa}$ protein. Biochim Biophys Acta. 1997; 1359:275-285. [PubMed: 9434133]

Thore S, Wuttke A, Tengholm A. Rapid turnover of phosphatidylinositol-4,5-bisphosphate in insulinsecreting cells mediated by $\mathrm{Ca}^{2+}$ and the ATP-to-ADP ratio. Diabetes. 2007; 56:818-826. [PubMed: 17327453]

Tomas A, Meda P, Regazzi R, Pessin JE, Halban PA. Munc 18-1 and granuphilin collaborate during insulin granule exocytosis. Traffic. 2008; 9:813-832. [PubMed: 18208509]

Torii S, Takeuchi T, Nagamatsu S, Izumi T. Rab27 effector granuphilin promotes the plasma membrane targeting of insulin granules via interaction with syntaxin 1a. J Biol Chem. 2004; 279:22532-22538. [PubMed: 15028737]

Tsuboi T. Molecular mechanism of attachment process of dense-core vesicles to the plasma membrane in neuroendocrine cells. Neurosci Res. 2009; 63:83-88. [PubMed: 19059288]

Tsuboi T, Fukuda M. The Slp4-a linker domain controls exocytosis through interaction with Munc18-1.syntaxin-1a complex. Mol Biol Cell. 2006; 17:2101-2112. [PubMed: 16481396]

van Meer G, Voelker DR, Feigenson GW. Membrane lipids: where they are and how they behave. Nat Rev Mol Cell Biol. 2008; 9:112-124. [PubMed: 18216768]

Voelker, DR. Lipid assembly into cell membranes. In: Vance, DE.; Vance, JE., editors. Biochemistry of Lipids, Lipoproteins and Membranes. 5th Ed.. Elsevier; Amsterdam: 2008. p. 441-484.

Wang H, Ishizaki R, Xu J, Kasai K, Kobayashi E, Gomi H, Izumi T. The Rab27a effector exophilin7 promotes fusion of secretory granules that have not been docked to the plasma membrane. Mol Biol Cell. 2013; 24:319-330. [PubMed: 23223571]

Wang J, Takeuchi T, Yokota H, Izumi T. Novel rabphilin-3-like protein associates with insulincontaining granules in pancreatic beta cells. J Biol Chem. 1999; 274:28542-28548. [PubMed: 10497219]

White SH, Wimley WC. Membrane protein folding and stability: physical principles. Annu Rev Biophys Biomol Struct. 1999; 28:319-365. [PubMed: 10410805]

Yi Z, Yokota H, Torii S, Aoki T, Hosaka M, Zhao S, Takata K, Takeuchi T, Izumi T. The Rab27a/ granuphilin complex regulates the exocytosis of insulin-containing dense-core granules. Mol Cell Biol. 2002; 22:1858-1867. [PubMed: 11865063]

Yu M, Kasai K, Nagashima K, Torii S, Yokota-Hashimoto H, Okamoto K, Takeuchi T, Gomi H, Izumi T. Exophilin4/Slp2-a targets glucagon granules to the plasma membrane through unique $\mathrm{Ca}^{2+}$-inhibitory phospholipid-binding activity of the C2A domain. Mol Biol Cell. 2007; 18:688696. [PubMed: 17182843] 


\section{Highlights}

Both granuphilin $\mathrm{C} 2$ domains bind lipids present in the plasma membrane: PS and $\mathrm{PIP}_{2}$

C2A binds liposomes containing $\mathrm{PIP}_{2}$ with high affinity $(2-5 \mathrm{nM})$

C2B binds liposomes containing PIP $_{2}$ with moderate affinity ( 200 nM)

The signaling molecule $\mathrm{IP}_{6}$ competes with anionic lipids for binding both domains 


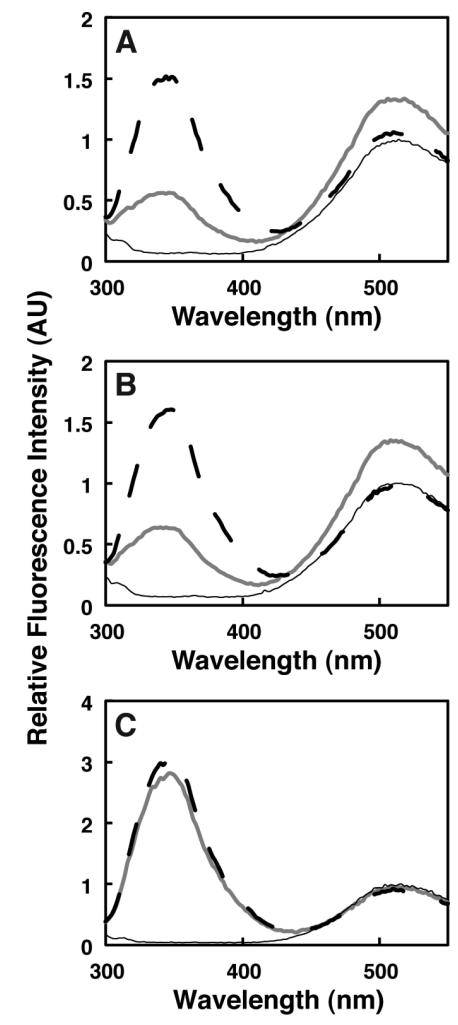

Figure 1. Qualitative FRET measurement of granuphilin C2A binding to lipid vesicles Fluorescence emission spectra are shown of $\mathrm{C} 2 \mathrm{~A}$ with $(\mathbf{A}) \mathrm{PM}_{(-) \mathrm{PIP}_{\mathrm{X}}}$,(B) $\mathrm{PM}(+) \mathrm{PIP}_{2}$, and (C) PC/dPE vesicles (lipid compositions given in Table 1). Thin black curves: blank measurements prior to protein addition, consisting of vesicles ( $125 \mu \mathrm{M}$ total accessible lipid) in assay buffer. The peak at $\sim 510 \mathrm{~nm}$ in these traces represents direct excitation of the dans fluorophore at $284 \mathrm{~nm}$. Thick gray curves: measurements after addition of $1 \mu \mathrm{M} \mathrm{C} 2 \mathrm{~A}$ domain. Dashed black curves: measurements after addition of $8 \mathrm{mM} \mathrm{IP}_{6}$. Protein-lipid binding is evidenced by increased dans emission at $\sim 510 \mathrm{~nm}$ due to FRET upon protein addition. Intensities in each panel are normalized to the maximum dans emission intensity of the sample prior to protein addition. 


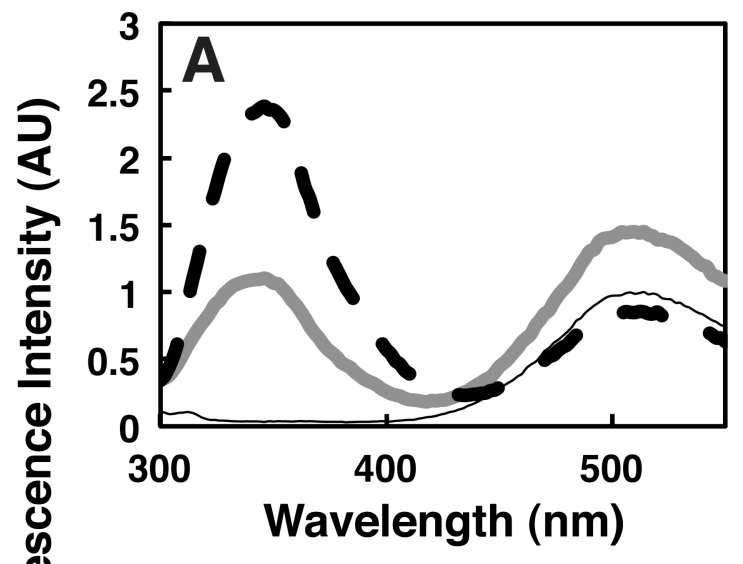

몬

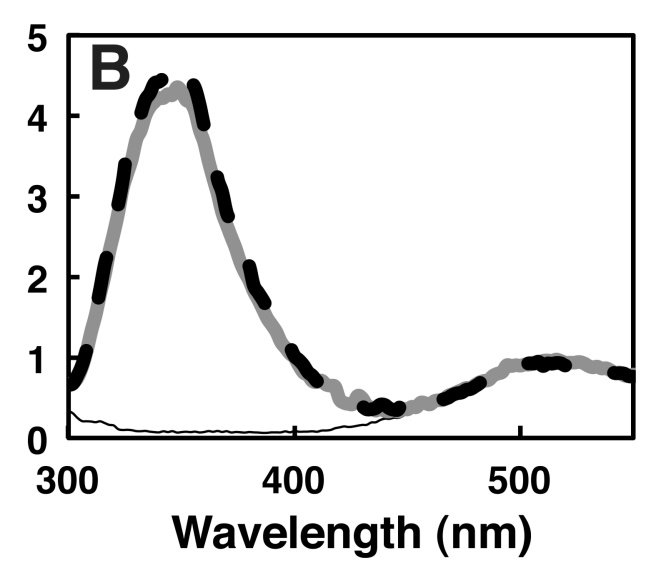

Figure 2. Granuphilin C2A interaction with background anionic lipids

Fluorescence emission spectra are shown as described in the legend to Figure 1, using vesicles composed of (A) PC/PS/PI/dPE and (B) PM(-)PIP $/ \mathrm{PS} / \mathrm{PI}$ (compositions given in Table 1). 


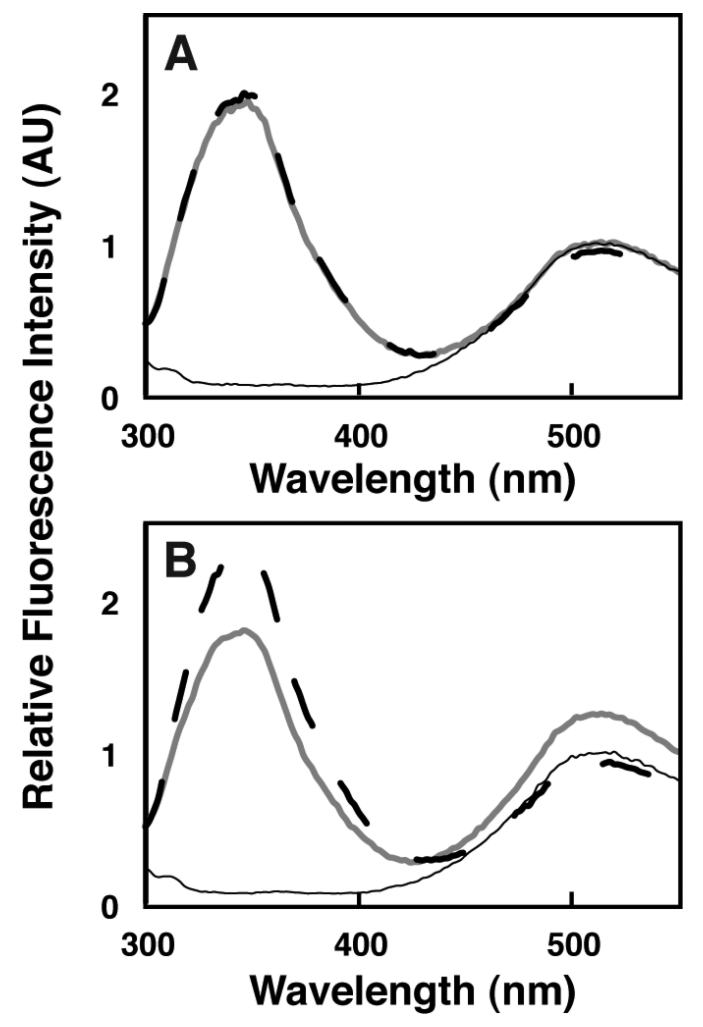

Figure 3. Qualitative FRET measurement of granuphilin C2B binding to lipid vesicles Fluorescence emission spectra are shown as described in the legend to Figure 1, using $1 \mu \mathrm{M}$ C2B domain and vesicles composed of (A) PM(-)PIP $\mathrm{P}_{\mathrm{x}}$ and (B) PM(+)PIP (compositions $^{2}$ given in Table 1). 


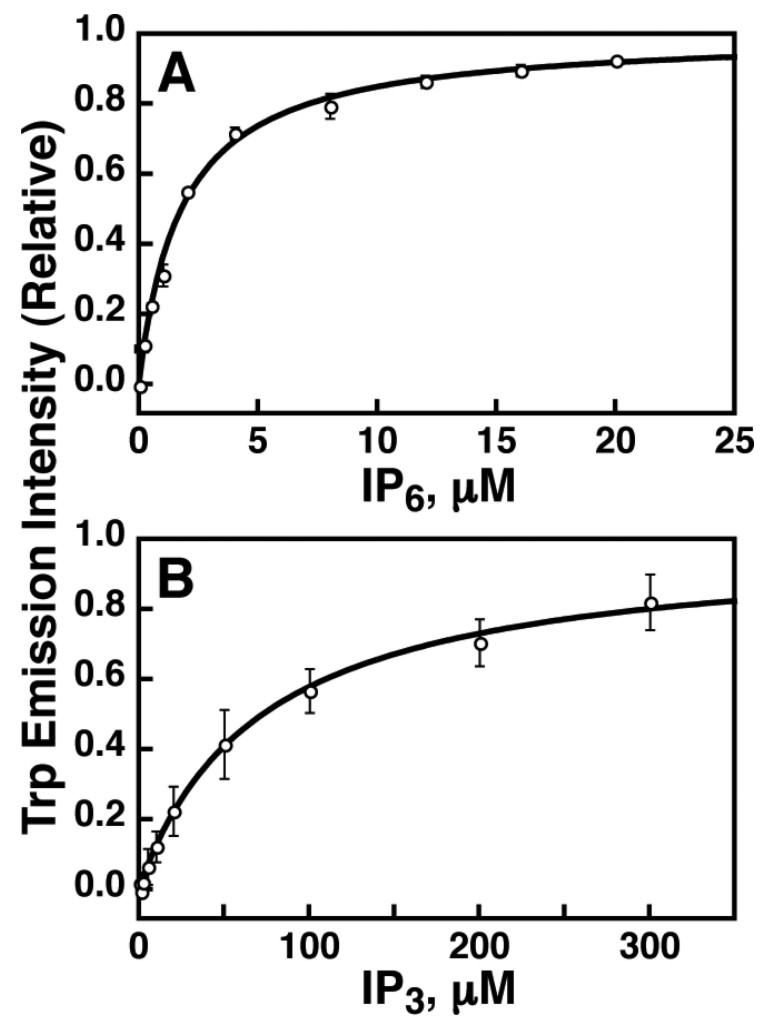

Figure 4. Equilibrium fluorescence measurement of granuphilin $\mathrm{C}_{2} \mathrm{~A}$ domain binding to (A) $\mathrm{IP}_{6}$ and $(\mathrm{B}) \mathrm{IP}_{3}$

Trp fluorescence intensity (excitation $284 \mathrm{~nm}$, emission $330 \mathrm{~nm}$ ) was monitored upon titration of ligand into solutions of $0.2 \mu \mathrm{M} \mathrm{C} 2 \mathrm{~A}$ in assay buffer. The fluorescence increase was fit to eq. 1 (solid curves) and intensity values were normalized as described in Methods (section 2.4). Best-fit values are given in section 3.2. Error bars show standard deviation of three independent replicate experiments; where not visible, error bars are smaller than the data symbols. 


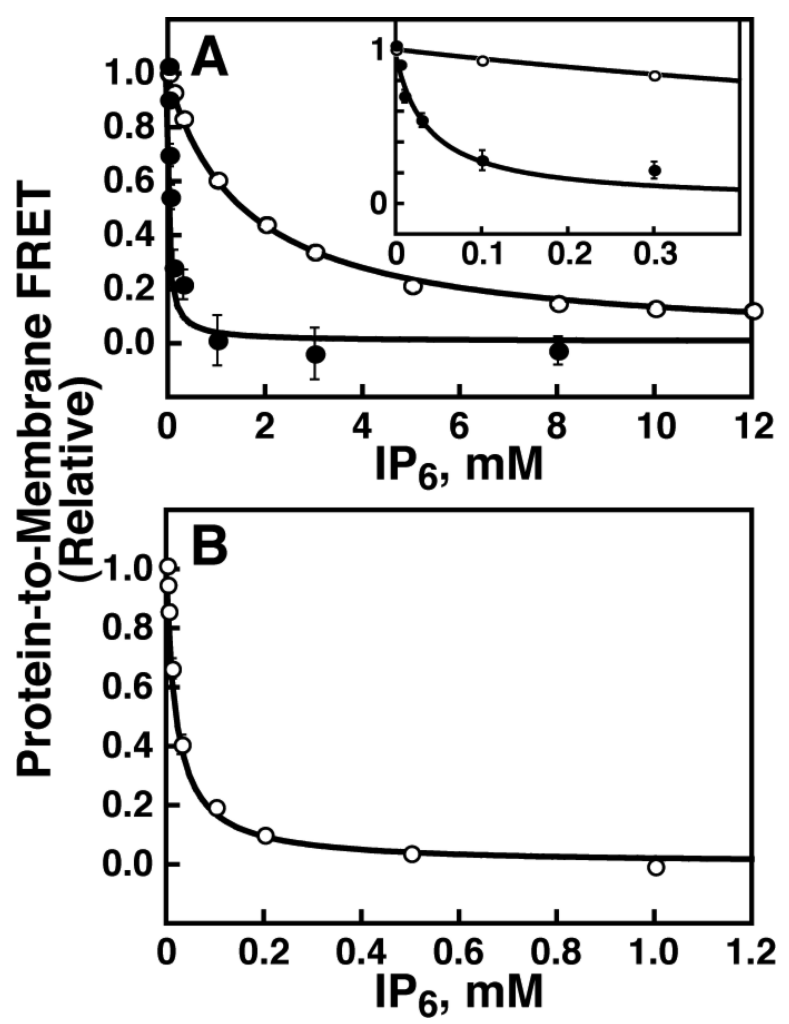

Figure 5. $\mathrm{IP}_{6}$ competition measurement of granuphilin $\mathrm{C} 2$ domain vesicle binding Protein-to-membrane FRET was monitored (excitation $284 \mathrm{~nm}$, emission $512 \mathrm{~nm}$ ) of (A) 1

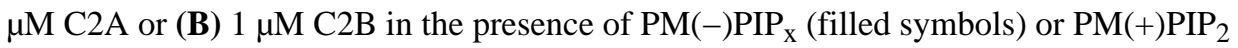
vesicles (open symbols) upon titration of $\mathrm{IP}_{6}$. The resultant FRET decrease was fit to eq. 2 (solid curves). Best-fit values are given in Table 2. Error bars are standard deviation of three independent replicate experiments, and where not visible are smaller than the data symbols. Inset to panel A: view expanded to show values at lower $\mathrm{IP}_{6}$ concentrations. 


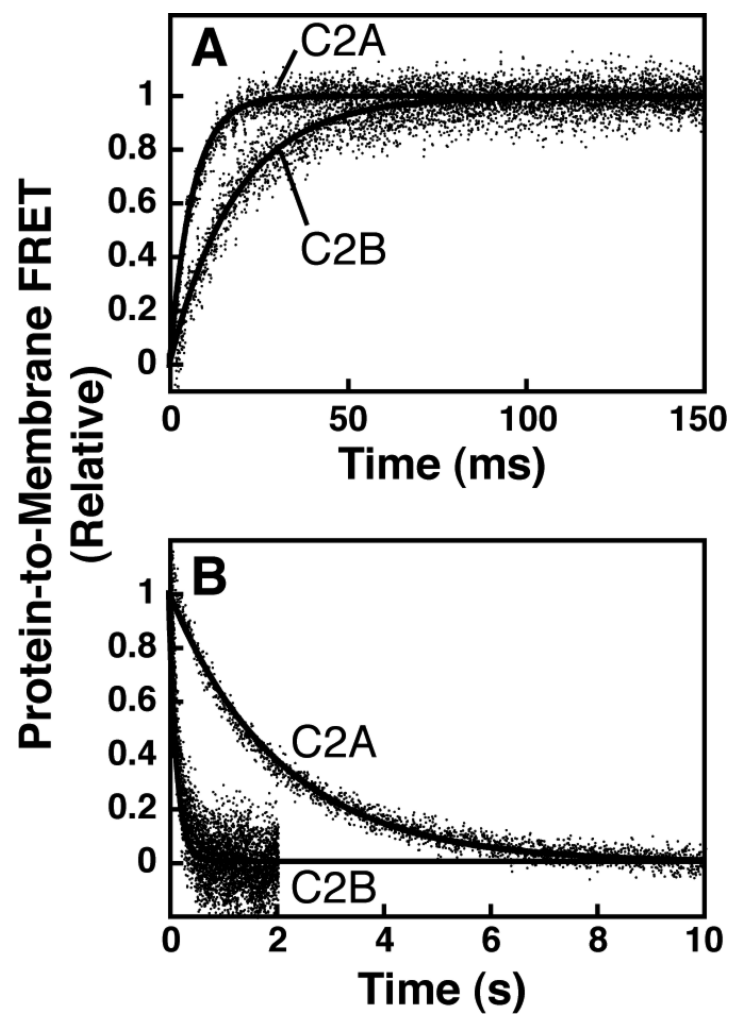

Figure 6. Kinetic measurement of granuphilin C2 domain membrane interaction

A: Association kinetics. Protein $(0.3 \mu \mathrm{M})$ was rapidly mixed with $\mathrm{PM}(+) \mathrm{PIP}_{2}$ vesicles $(75$ $\mu \mathrm{M}$ total accessible lipid after mixing) in a stopped-flow fluorescence spectrometer and the increase in dans emission was monitored (excitation $284 \mathrm{~nm}$ ). Single-exponential fits are shown (black curves, eq. 6). B: Dissociation kinetics. Protein $(0.3 \mu \mathrm{M})$ was pre-bound to $\mathrm{PM}(+) \mathrm{PIP}_{2}$ vesicles $(75 \mu \mathrm{M}$ total accessible lipid, all concentrations after mixing) and rapidly mixed with excess $\mathrm{PM}(+) \mathrm{PIP}_{2}$ vesicles lacking dansyl-PE $(300 \mu \mathrm{M}$ total accessible lipid). Single-exponential fits are shown (black curves, eq. 5). Data points are averages from 9-12 mixing events. The smaller signal-to-noise ratios for $\mathrm{C} 2 \mathrm{~B}$ are due to the smaller amplitude of its FRET change upon membrane binding (compare Figure 3B to Figure 1B). 

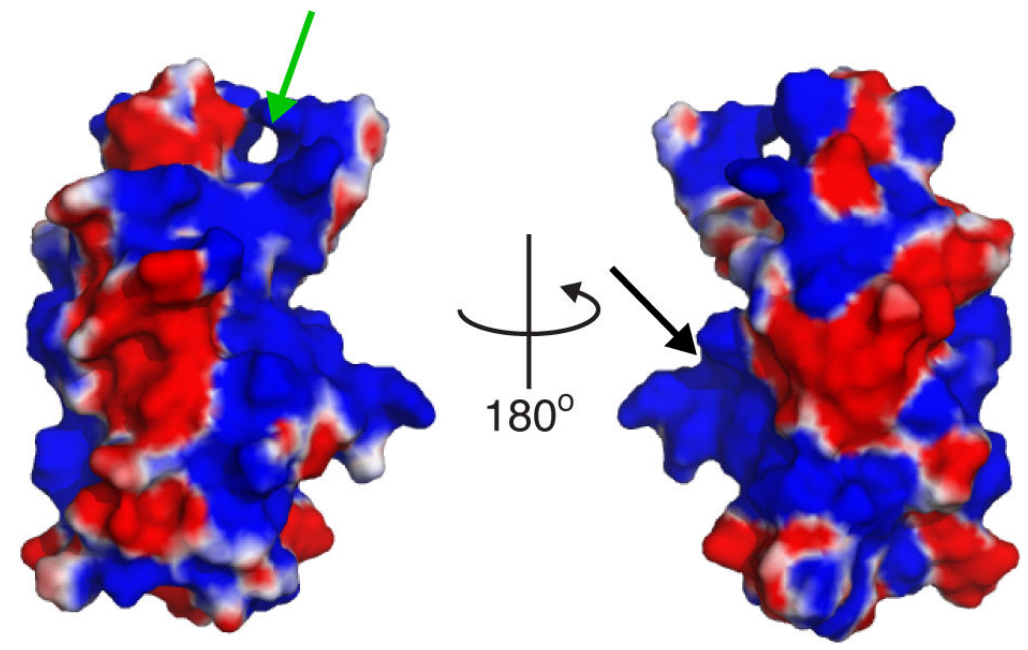

Figure 7. Electrostatic surface representation of granuphilin $\mathrm{C2A}$

Surface electrostatic potentials are shown colored from -3 (red) to +3 (blue). Green arrow: putative binding site consisting of residues in the $\beta 2-\beta-3$ and $\beta 6-\beta 7$ loops, which correspond to the $\mathrm{Ca}^{2+}$ binding loops of synaptotagmin $\mathrm{C} 2$ domains. Black arrow: putative binding site including residues $\mathrm{K} 410, \mathrm{R} 411$, and $\mathrm{K} 412$, homologous to the $\mathrm{PIP}_{2}$ binding site of synaptotagmin 1 C2B (Radhakrishnan et al., 2009). Potential map calculated using the APBS plugin for Pymol. 


\begin{tabular}{|c|c|c|c|c|c|c|c|c|c|c|}
\hline 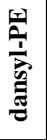 & $n$ & in & in & in & in & in & in & in & in & in \\
\hline$\hat{\Xi}$ & 0 & $\mathrm{a}$ & 0 & 0 & 0 & 0 & 0 & 0 & 0 & 0 \\
\hline$\hat{E}$ & 4 & 0 & 0 & 0 & 0 & 0 & 0 & 0 & 0 & 0 \\
\hline$\sum$ & $\stackrel{n}{f}$ & $\stackrel{n}{+}$ & $\stackrel{n}{f}$ & 年 & $\stackrel{n}{f}$ & 0 & 0 & 0 & 0 & 0 \\
\hline ت & $\ddot{\sim}$ & $\ddot{\imath}$ & $\ddot{\sim}$ & $\ddot{2}$ & 2 & 0 & 0 & 0 & 0 & 0 \\
\hline 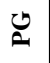 & 0 & 0 & 0 & 0 & $\grave{\lambda}$ & 0 & 0 & 0 & A & 0 \\
\hline$\Xi$ & + & 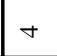 & 0 & 0 & 0 & 0 & 0 & $\stackrel{\sim}{\sim}$ & 0 & 0 \\
\hline 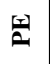 & $\underset{\sim}{\infty}$ & $\underset{\sim}{\infty}$ & $\underset{\sim}{\infty}$ & $\mid \infty \underset{\sim}{\infty}$ & $\underset{\sim}{\infty}$ & 0 & 0 & 0 & 0 & 0 \\
\hline$\approx$ & $\vec{\sim}$ & $\vec{\sim}$ & $\vec{\sim}$ & 0 & O & 0 & $\dot{U}$ & 0 & 0 & $\bar{\lambda}$ \\
\hline 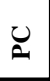 & $\stackrel{n}{\varrho}$ & $\stackrel{n}{\varrho}$ & $\stackrel{n}{\varrho}$ & $\begin{array}{l}n \\
m \\
m\end{array}$ & $\stackrel{n}{\varrho}$ & $\approx$ & $\approx$ & $\approx$ & $\approx$ & $\infty$ \\
\hline & 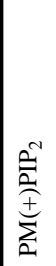 & 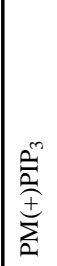 & 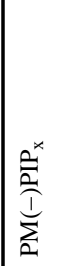 & 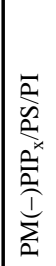 & 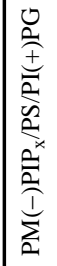 & 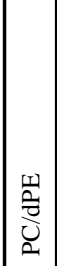 & 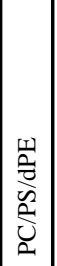 & 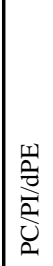 & 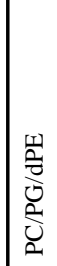 & 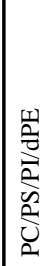 \\
\hline
\end{tabular}


Table 2

Parameters from $\mathrm{IP}_{6}$ competition measurements

\begin{tabular}{|c|c|c|c|c|c|c|}
\hline Domain & Target vesicles & $\mathrm{IC}_{50}\left(\mathrm{IP}_{6}\right), \mu \mathrm{M}^{a}$ & $K_{\mathrm{x}} \times 10^{-6} b$ & Apparent $K_{\mathrm{d}, \mathrm{PIPx}}, \mathrm{nM}^{c}$ & $\Delta \mathbf{G}_{\mathrm{x}}^{\circ}, \mathrm{kcal} / \mathrm{mol}$ & $\Delta \mathrm{G}_{\mathrm{PIPx}}^{\circ}, \mathrm{kcal} / \mathrm{mol}$ \\
\hline $\mathrm{C} 2 \mathrm{~A}$ & $\mathrm{PM}(+) \mathrm{PIP}_{2}$ & $1600 \pm 200$ & $390 \pm 70$ & $2.3 \pm 0.4$ & $-11.7 \pm 0.1$ & $-11.8 \pm 0.1$ \\
\hline $\mathrm{C} 2 \mathrm{~A}$ & $\mathrm{PM}(+) \mathrm{PIP}_{3}$ & $1100 \pm 100$ & $270 \pm 40$ & $3.3 \pm 0.5$ & $-11.5 \pm 0.1$ & $-11.6 \pm 0.1$ \\
\hline $\mathrm{C} 2 \mathrm{~A}$ & $\mathrm{PM}(-) \mathrm{PIP}_{\mathrm{x}}$ & $37 \pm 6$ & $9 \pm 2$ & N.D. ${ }^{d}$ & $-9.5 \pm 0.1$ & N.D. ${ }^{d}$ \\
\hline $\mathrm{C} 2 \mathrm{~A}$ & $\mathrm{PC} / \mathrm{PS} / \mathrm{dPE}$ & $10 \pm 1$ & $2.1 \pm 0.4$ & N.D. ${ }^{d}$ & $-8.6 \pm 0.1$ & N.D. ${ }^{d}$ \\
\hline $\mathrm{C} 2 \mathrm{~A}$ & $\mathrm{PC} / \mathrm{PI} / \mathrm{dPE}$ & $5 \pm 1$ & $0.8 \pm 0.1$ & N.D. ${ }^{d}$ & $-8.1 \pm 0.1$ & N.D. ${ }^{d}$ \\
\hline $\mathrm{C} 2 \mathrm{~A}$ & $\mathrm{PC} / \mathrm{PG} / \mathrm{dPE}$ & $11 \pm 1$ & $2.2 \pm 0.3$ & N.D. ${ }^{d}$ & $-8.6 \pm 0.1$ & N.D. ${ }^{d}$ \\
\hline $\mathrm{C} 2 \mathrm{~B}$ & $\mathrm{PM}(+) \mathrm{PIP}_{2}$ & $21 \pm 3$ & N.D. ${ }^{e}$ & N.D. ${ }^{e}$ & N.D. ${ }^{e}$ & N.D. ${ }^{e}$ \\
\hline
\end{tabular}

${ }^{a}$ IC50 values and errors are average and standard deviation of 3 or more independent replicate experiments.

${ }^{b}$ Mole-fraction partition coefficient, calculated using eq. 3 .

${ }^{c}$ Calculated using eq. 4 .

${ }^{d}$ Apparent $K_{\mathrm{d}, \mathrm{PIPx}}$ not calculated for vesicles lacking PIP ${ }_{\mathrm{X}}$.

${ }^{e}{ }_{\text {IP } 6}$ binding does not alter the intrinsic Trp fluorescence of $\mathrm{C} 2 \mathrm{~B}$, therefore its $K_{\mathrm{I}}$ was not measured using this method. 
Table 3

Measured rate constants from kinetic experiments

\begin{tabular}{|l|l|l|l|l|l|}
\hline Domain & Target vesicles & $\boldsymbol{k}_{\text {off }}, \mathbf{s}^{-\mathbf{1}} \boldsymbol{a}$ & $\begin{array}{l}\boldsymbol{k}_{\text {obs }} \text { for association, } \\
\mathbf{s}^{\mathbf{1}} \boldsymbol{a}, \boldsymbol{b}\end{array}$ & $\begin{array}{l}\boldsymbol{k}_{\text {on }} / \boldsymbol{k}_{\text {off }} \times \mathbf{1 0}^{-\mathbf{6}} \text { expressed as } \\
\text { partition coefficient }\end{array}$ & $\begin{array}{l}\boldsymbol{k}_{\text {off }} / \boldsymbol{k}_{\text {on }}, \mathbf{n M}^{\boldsymbol{c}} \text { expressed as } \\
\text { affinity for } \mathbf{P I P}_{\mathbf{2}}\end{array}$ \\
\hline $\mathrm{C} 2 \mathrm{~A}$ & $\mathrm{PM}(-) \mathrm{PIP}_{\mathrm{x}}$ & $13 \pm 1$ & $190 \pm 30$ & $10 \pm 2$ & N.D. ${ }^{d}$ \\
\hline $\mathrm{C} 2 \mathrm{~A}$ & $\mathrm{PM}(+) \mathrm{PIP}_{2}$ & $0.48 \pm 0.01$ & $150 \pm 20$ & $230 \pm 40$ & $4.3 \pm 0.7$ \\
\hline $\mathrm{C} 2 \mathrm{~B}$ & $\mathrm{PM}(+) \mathrm{PIP}_{2}$ & $6.9 \pm 0.1$ & $54 \pm 8$ & $5 \pm 1$ & $200 \pm 40$ \\
\hline
\end{tabular}

${ }^{a}$ Values and errors shown are average and standard deviation of fits to 3 or more replicate measurements.

${ }^{b}$ Measured using $75 \mu \mathrm{M}$ total accessible lipid.

${ }^{c}$ Values of $k_{\text {on }}$ were calculated using eqs. 7 and 8.

$d_{\text {Not calculated for vesicles lacking PIP2. }}$. 